\title{
OPEN
}

\section{Publisher Correction: Detection of introduced and resident marine species using environmental DNA metabarcoding of sediment and water}

\author{
Luke E. Holman $\mathbb{D}^{\mathrm{D}}$, Mark de Bruyn $\mathbb{D}$, Simon Creer $(\mathbb{D}$, Gary Carvalho, Julie Robidart \& \\ Marc Rius iD
}

Correction to: Scientific Reports https://doi.org/10.1038/s41598-019-47899-7, published online 09 August 2019

The original version of this Article contained extensive errors in the Reference list. Reference 46 was incorrectly listed as Reference 92, and References 47-92 were incorrectly listed as References 46-91 respectively.

Additionally, there was a typographical error in the Methods.

"Records from rapid assessment surveys previously conducted for non-native invertebrates at the sample sites ${ }^{47-49}$ were compared with the detected species from metabarcoding data."

should read:

"Records from rapid assessment surveys previously conducted for non-native invertebrates at the sample sites ${ }^{48-50}$ were compared with the detected species from metabarcoding data."

These errors have now been corrected in the PDF and HTML versions of the Article.

(c) (i) Open Access This article is licensed under a Creative Commons Attribution 4.0 International License, which permits use, sharing, adaptation, distribution and reproduction in any medium or format, as long as you give appropriate credit to the original author(s) and the source, provide a link to the Creative Commons license, and indicate if changes were made. The images or other third party material in this article are included in the article's Creative Commons license, unless indicated otherwise in a credit line to the material. If material is not included in the article's Creative Commons license and your intended use is not permitted by statutory regulation or exceeds the permitted use, you will need to obtain permission directly from the copyright holder. To view a copy of this license, visit http://creativecommons.org/licenses/by/4.0/.

(C) The Author(s) 2020 